\title{
Noise Cancellation Using Non-LocalMeans SVD
}

\author{
Muhammad Eka Suryana \\ Universitas Negeri Jakarta \\ eka-suryana@unj.ac.id
}

\begin{abstract}
Abstrak - image denoising merupakan upaya untuk menghilangkan noise dari citra digital. Sejumlah teknik untuk denoising menggunakan prinsip pemisahan sinyal asli dan sinyal noise. Tidak seperti sejumlah teknik yang melakukan pendekatan ini. Non local means merupakan teknik denoising untuk mendapatkan citra asli menggunakan weighted similarities antara piksel. Tulisan ini merupakan laporan investigasi mengenai NLM algoritma tersebut dan NLM yang telah terimprovisasi menggunakan SVD.
\end{abstract}

Keywords-component; Image Denoising, NLM

\section{PENDAHULUAN}

Citra digital dapat terkorupsi akibat keterbatasan perangkat pencitraan(Kamera) dalam menangkap detail citra dalam format digital, atau kesengajaan. Salah satu bentuk citra terkorupsi adalah munculnya artifak pada sebagian atau seluruh piksel yang menyebabkan nilai piksel yang terkorupsi terdeviasi dari nilai piksel asli sehingga membuat citra yang terkena noise mengalami penurunan kualitas visual. Misalkan $N_{o}$ merupakan citra asli, $N_{f}$ merupakan noise, dan $N_{i}$ merupakan citra asli yang terkena noise. Relasi antara citra ketiga elemen tersebut dapat dinotasikan dengan,

$$
N_{i}=N_{o}+N_{f}
$$

Citra asli dapat dikembalikan dengan memisahkan $N_{f}$ dari $N_{i}$, namun dalam praktik denoising hanya informasi $N_{i}$ yang diketahui. Seandainya noise dapat diestimasi dengan baik maka, denoising akan memberikan citra yang mendekati citra asli. Salah satu bentuk estimasi noise adalah dengan menganggap noise memiliki properti berfrekuensi tinggi, sehingga $N_{o}$ didapatkan dengan mengurangi frekuensi tinggi dari $N_{i}$. Metode yang menerapkan prinsip ini dinamakan dengan frequency domain filter, derivatifnya antara lain wiener filter, wavelet tresholding, total variant minimation. Citra gambar yang dikembalikan menggunakan pendeketan pemisahan frekuensi rendah dari frekuensi tinggi, memiliki keterbatasan detail tekstur dari gambar juga hilang karena tekstur merupakan pola yang berfrekuensi tinggi.

Non-local Means(NLM) merupakan metode denoising yang cukup efektif untuk menghilang white noise/gaussian noise dengan mean 0 dan variance tertentu. NLM memiliki asumsi bahwa setiap citra gambar bersifat redundan/repetitif, lebih detailnya: nilai piksel pada koordinat spasial citra sangat mungkin memiliki nilai piksel yang berdekatan pada koordinat spasial lainnya pada citra yang sama. Memanfaatkan informasi ini, NLM merestorasi citra asli dengan melakukan averaging nilai piksel yang berdekatan tersebut. Nilai piksel yang similar ini sangat mungkin ditemui pada daerah tetangga piksel tersebut, namun tidak menutup kemungkinan ditemukan juga pada piksel yang berjarak spasial cukup jauh dari piksel referensi.

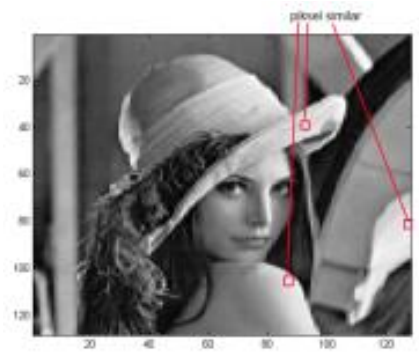

Gambar la. Citra asli

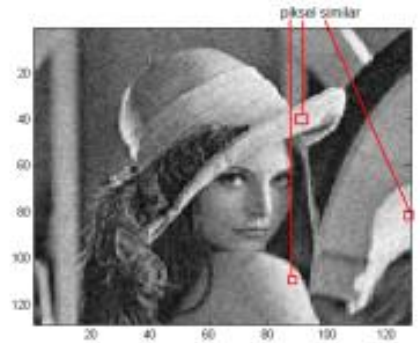

Gambar 1b. Citra terkorupsi white nowise
Karena informasi kelompok piksel yang memiliki nilai berdekatan(relevan) tidak diketahui. NLM yang diperkenalkan Buades et al(2005), melakukan denoising dengan melakukan weighted averaging piksel referensi(POI - pixel of interest) dengan seluruh piksel selain piksel tersebut. Piksel yang memiliki kedekatan nilai akan diberikan weight maksimum, jika tidak weight diset minimum. Setelah semua weight dihitung untuk POI, dilakukan averaging untuk mendapatkan nilai piksel terestorasi untuk POI.

Piksel-piksel yang relevan diukur dari citra gambar asli. Misalkan sebelum terkorupsi POI A memiliki nilai 100, untuk suatu waktu ditemukan piksel yang relevan sebut B \& C masing-masing memiliki nilai $98 \& 103$. Setelah diberikan noise, nilai $\mathrm{A}:=110, \mathrm{~B}:=88, \mathrm{C}:=92$. Oleh sebab ini proses averaging per pixel tidak akan memberikan hasil yang optimal. NLM melakukan averaging terhadap neighborhood piksel POI dengan neighborhood piksel yang relevan, sebab bisa jadi masih terdapat piksel tetangga B \& C yang tidak banyak terkorupsi, dan informasi itulah yang dilibatkan dalam perhitungan avaraging antara dua buah neighborhood yang relevan. Atas dasar yang sama, dapat dianggap NLM tidak berpengaruh besar, untuk citra yang banyak terkorupsi noise. Sebab akan piksel yang benar-benar relevan terhadap POI akan berjumlah minoritas.

Notasi matematis dari metode NLM dapat direpresentasikan dengan formula berikut:

$$
\begin{gathered}
w_{i j}= \\
\exp \left\{-\frac{\left|G a \cdot\left(x_{i}-x_{j}\right)\right|^{2}}{h^{2}}\right\}
\end{gathered}
$$




$$
y_{i}=\frac{\sum w_{i j} \cdot x_{j}}{\sum w_{i j}}
$$

Dimana:

$W_{i j}$ : Weight similaritas dua neighborhood piksel. • berarti perkalian element-wise.

$h$ : Estimasi noise variance yang terkandung dalam seluruh citra terkorupsi noise.

$G a$ : Kernel gaussian 2-D yang berukuran sama dengan ukuran neighborhood piksel.

$x_{j}$ : Nilai piksel dengan indeks ke-j yang diperbandingkan.

$x_{i}$ : Nilai piksel POI. .

$y_{i}$ : Piksel POI yang telah di-denoising

Gaussian kernel dapat dhitung menggunakan formula berikut,

$$
G a=\frac{1}{R} \sum_{i=m}^{R} \frac{1}{(2 i+1)^{2}}
$$

Nilai $2 . i+1$ pada formula $p 3$ merupakan derajat elevasi kurva gaussian, nilai ini dapat dirubah sesuai kebutuhan. Kernel gaussian memiliki properti unik, dimana pada array(1D)/matriks(2-D) yang dihasilkan dari fungsi gaussian nilai dominan berada pada indeks tengah, dan semakin menurun untuk indeks yang menjauhi indeks tengah.

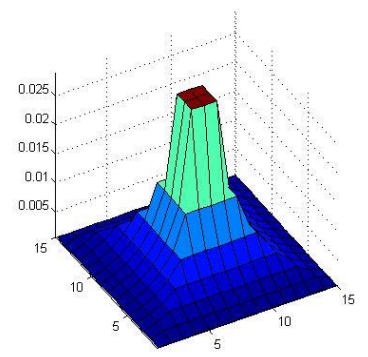

Gambar 1. Plot 2-D kernel gaussian ukuran 7x7

\section{FONDASI}

\section{A. Lingkungan Eksperimen}

NLM dibuat pertama kali menggunakan Java menggunakan framework Marvin. kemudian diporting ke kode Matlab, hal ini dilakukan sebab Matlab menyediakan banyak Application Programming Interface/API/fungsi untuk dukungan komputasi numerik.SVD merupakan salah satu fitur yang dipergunakan untuk pengembangan NLM dengan SVD.

\section{B. Noise}

Prinsip pemisahan noise dari citra gambar yang terkorupsi noise merupakan cara yang ideal untuk denoising, meskipun perfect estimation of noise values sama sulitnya dengan denoising. Namun pemahaman karakteristik berbagai jenis noise merupakan dasar kerangka berpikir untuk denoising. Menganalisa karakteristik noise akan membantu dalam menentukan metode yang tepat untuk denoising, dan memahami mengapa NLM efektif untuk white noise.

Noise merupakan nilai deviasi dari nilai piksel sebenarnya, nilai intensitas piksel bernilai 0-255 sehingga noise juga berada pada interval yang sama. Noise diukur berdasarkan nilai variance, hal ini berlaku untuk white noise.

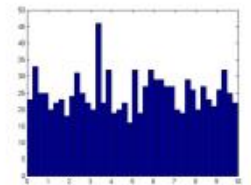

(a) Histogram uniform

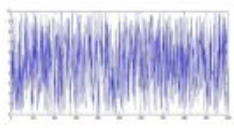

(d) Sinyal noise uniform

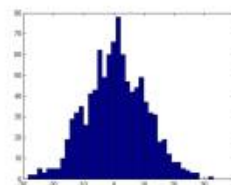

(b) Histogram gaussian

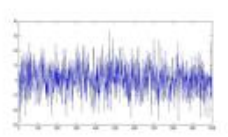

(e) Sinyal noise gauss

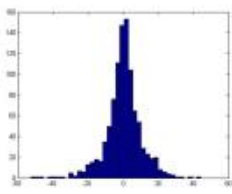

(c) Histogram eksponensial

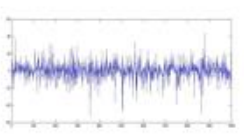

(f) Sinyal noise exponential
Gambar 3. Histogram noise(atas) \& Plot sinyal noise (bawah), 1000 elemen, sigma=10.

White noise/gaussian noise memiliki karakteristik: bilangan random yang dihasilkan berada dalam rentang nilai bilangan signed integer dan memiliki histogram gaussian dengan mean 0 , dan kerampingan(skewness) tertentu yang dihitung berdasarkan sigma/standar deviasi(gambar 3.a). Untuk noise uniform, bilangan random yang dihasilkan berada dalam rentang positif integer dan memiliki distribusi histogram uniform(gambar 3.b). Untuk noise exponential, rentang nilai bilangan random yang dihasilkan berupa signed integer dan memiliki distribusi histogram exponential(gambar 3.c).

\section{Non-local Means SVD}

NLM melakukan averaging terhadap seluruh piksel. Proses ini memiliki kompleksitas waktu yang mahal, $O\left(N^{4}\right)$. Untuk mengurangi waktu kompleksitas kinerja NLM dapat dibatasi dengan melakukan averaging pada search window yang ditentukan. Karena piksel tetangga seringkali memiliki nilai piksel yang berdekatan, pembatasan search window tidak terlalu mempengaruhi kinerja denoising.

Denoising akan optimal jika jumlah piksel yang relevan dominan. Karena informasi piksel mana saja yang relevan mula-mula tidak diketahui, implementasi NLM original memanfaatkan weighted averaging. Jika piksel mana saja yang relevan dapat diestimasi dengan baik hasil denoising yang didapatkan akan lebih optimal. Orchard, 2008 memperkenalkan metode find most relevant patch(MRP) yang dihitung menggunakan SVD. Pencarian MRP menggunakan SVD bersifat fundamental sehingga diadaptasi dan diperbaiki oleh penelitian yang lain, seperti Thaipanich(2010) yang memanfaatkan SVD untuk menghitung gradient sehingga tekstur dapat lebih dipertahankan setelah denoising dan neighborhood rotated matching untuk mencari MRP. Dua neighborhood window piksel bisa jadi tidak memiliki nilai similaritas yang sama, namun setelah dilakukan neighborhood window rotation pada piksel yang diperbandingkan bisa jadi nilai similaritas meningkat. MRP yang ditentukan menggunakan SVD memiliki kelemahan, signal subspace yang 
didapatkan over estimate menggunakan local basis training Yanmin He mendapatkan patch yang lebih relevan[6].

Prinsip kerja SVD memiliki kemiripan dengan pemisahan noise dan signal pada citra yang terkorupsi. Asumsi yang dipergunakan oleh metode SVD, jika citra terkorupsi noise maka signal subspace akan terletak pada lower dimensional moneyfold, sementara noise subspace akan terdapat pada remainder dimensional moneyfold. Misalkan terdapat citra sebuah gambar sebut sebagai $M$. SVD mendekomposisi $M$ menjadi eigen vektor kiri $U$, nilai eigen $S$, dan eigen vektor kanan $V$. Hubungan tersebut dapat direpresentasikan berdasarkan formula berikut.

$$
U S V^{t}=M
$$

Nilai eigen yang paling utama terdapat pada rank 1 dari matriks $S$. Semakin meningkat rank nilai eigen pada matriks $S$, semakin menurun keutamaannya. Hal inilah yang disebut lower dimensional moneyfold. Aproksimasi ruang sinyal dapat dilakukan dengan memilih rank $k(1 \leq k \leq \sim)$ tertentu, $k$ dipilih sedemikian rupa sehingga didaptkan aproksimasi terbaik.

\section{Hipotesa 1:}

"Signal subspace pada citra terkorupsi terdapat pada aproksimasi rank ke $k$ dari lower dimensional monefold."

Indikasi kebenaran signal subspace berada pada lower dimensional monefold dapat dilakukan dengan melakukan svd pada dua citra: citra asli dan citra terkorupsi noise. Jika dekomposisi rank 1 lower dimensional moneyfold dari kedua citra memberikan hasil yang berdekatan, hal tersebut mengindikasikan hipotesa 1 memiliki nilai kebenaran. Citra asli dan citra terkorupsi yang dipergunakan untuk mendapatkan signal subspace menggunakan gambar 1 , namun citra lebih banyak dikorupsi dengan $\sigma=20$.

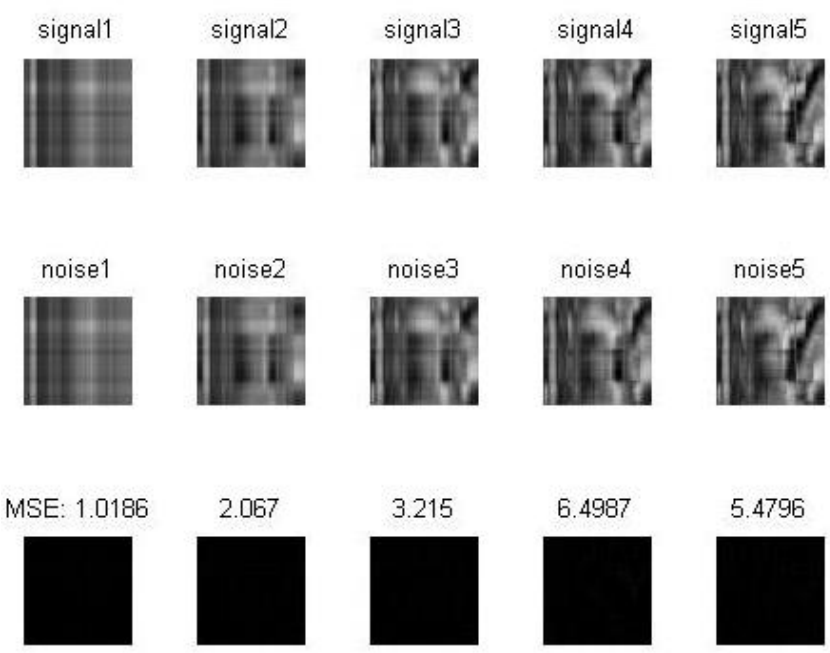

Gambar 2. Aproksimasi rank- $k$ dari Signal Subspace. Signal subspace dari citra asli(baris 1), dan citra terkorupsi(baris 2).
Signal space diaproksimasi terhadap kedua citra, menggunakan aproksimasi SVD rank 1 sampai 5. Perhitungan mean square error(MSE) dilakukan untuk mengetahui difference dari kedua citra aproksimasi. Hingga maksimum rank-5 yang diujikan diketahui MSE masih bernilai minimal. Informasi ini mengindikasikan untuk citra terkorupsi beberapa tingkat rank aproksimasi memberikan signal subspace yang sangat berdekatan dengan citra sebelum terkorupsi.

\section{Hipotesa 2:}

"Noise subspace pada citra terkorupsi akan berada pada aproksimasi remainder rank ke $k$ hingga rank $n$. dimana $n$ merupakan rank maksimum dari citra $M$."

Pembuktian hipotesa ini tidak dapat dilakukan dengan eksperimen. Misalkan mula-mula terdapat citra asli $M$, dan citra terkorupsi $M_{k}$. Difference dari $M_{k}-M$ kemudian disimpan dalam $D$. Aproksimasi dilakukan dengan mengambil rank $k=50$, dengan rank $n=128$. Histogram dan difference antara $D$ dan aproksimasi rank-50. Dapat dilihat pada gambar berikut.

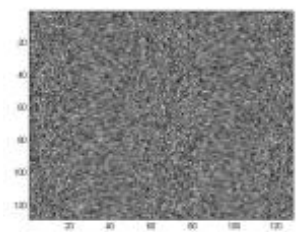

(a) Gaussian Noise

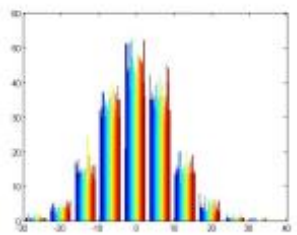

(c) Histogram noise gauss $\sigma=20$

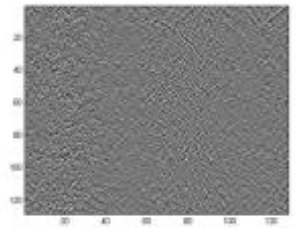

(b) Aproksimasi noise subspace $(k=60, n=128)$

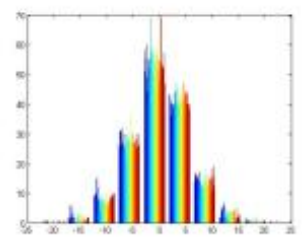

(d) Histogram aproksimasi noise subspace

\section{Gambar 3. Noise Subspace}

Berdasarkan informasi yang terdapat pada gambar 5, dapat disimpulkan hal-hal berikut:

- Aproksimasi remainder rank menggunakan SVD memberikan citra gambar yang jauh dari aslinya, citra aproksimasi lebih memiliki karakteristik noise.

- Meskipun karakteristik remainder rank approximation memiliki karakteristik noise. Namun perbedaan tekstur noise asli dengan aproksimasi noise terlalu jauh. Aproksimasi noise masih menyimpan sedikit informasi tekstur(tekstur topi pada gambar 5.b). Pemisahan langsung noise dari citra terkorupsi bukan cara yang tepat. Aproksimasi noise signal tidak akan pernah mendekati noise signal sebenarnya.

- Percobaan dilakukan berulang kali hingga mendapatkan histogram distribusi yang sangat mendekati distribusi histogram sinyal noise. Selain 
menggunakan aproksimasi $k=60$, dan $n=$ maksimal,. konfigurasi yang lain memiliki internval intensitas yang jauh dari noise signal sebenarnya dan histogram distribusi yang terbentuk memiliki skewness yang tidak mirip. Permasalahan menentukan histogram distribusi yang mendekati histogram signal noise merupakan kesulitan tersendiri.

Salah satu perbedaan ide yang diperkenalkan Orchard(2008)[3] dengan adaptif SVD yang digagas oleh Yanmin He(2011)[6] adalah Orchard hanya mempertimbangkan hipotesa 1 dalam algoritmanya sementara Yanmin $\mathrm{He}$ turut memasukkan hipotesa 2 dalam pengembangan algoritma. Re-eksperimentasi yang dilakukan penulis hanya membuktikan kebenaran gagasan yang diperkenalkan oleh Orchard.

Metode yang diperkenalkan oleh Orcard dapat diimplementasikan dengan langkah-langkah berikut:

- Untuk setiap piksel $i$ yang terdapat pada citra, buat matriks neighborhood window-nya. Setiap matriks neighborhood window yang terbentuk kemudian direshape menjadi sebuah vektor kolom.

- Merge setiap vektor neighorhood kolom menjadi sebuah matriks yang berukuran $m \times n(n>m$ kolom berjumlah lebih banyak dari baris). Sebut matriks yang terbentuk sebagai $Z$.

- Lakukan dekomposisi SVD dari matriks Z sehingga terdekomposisi menjadi matriks $U, S$, dan $V$.

- Menggunakan right singular vector $V$, hitung koordinat $C$ menggunakan formula $C=Z \times V$. Koordinat $C$ akan memiliki ukuran yang sama dengan $Z$, dan representasi koordinat piksel ke- $i$ dapat diakses melalui indeks kolom dari $C$.

MRP dapat dicari dengan menghitung L2 norm antara POI ke- $x$ dengan piksel selainnya. Misalkan $\alpha_{1}$ merupakan koordinat pertama dari $x$ dan $\beta_{1}$ merupakan koordinat pertama dari piksel selain $x$. Aproksimasi rank-1 L2 norm dapat dihitung dengan $\left(\alpha_{1}-\beta_{1}\right)^{2}$. MRP akan memiliki norm yang kecil sehingga eliminasi piksel yang memberikan perhitungan norm besar, hal ini dapat dilakukan salah satunya dengan mensort nilai norm, kemudian simpan sejumlah norm terkecil menggunakan rasio tertentu. Pada percobaan yang dilakukan rasio ditentukan sebesar 5\%. Untuk citra berukuran $128 \times 128$. $C$ yang terbentuk akan memiliki panjang 16.384 , menggunakan treshold 5\% akan menyisakan MRP sejumlah 819. Untuk mengerucutkan MRP, misalkan rank-1 L2 norm yang telah dihitung dinotasikan dengan norm-1, aproksimasi rank norm berikutnya dhitung menggunakan norm $-2=$ norm $-1+$ norm -2 . Rasio untuk aproksimasi norm subsekuen rank berikutnya diset sebesar $80 \%-90 \%$ tentatif. Total rank aproksimasi yang dipergunakan oleh Orchard $k=20$.

Implementasi NLM MRP yang dilakukan sedikit berbeda karena terdapat perbedaan persepsi. Perbedaan tersebut terletak pada dua hal: Koordinat yang penulis implementasikan didapat dengan menyelesaikan sistem persamaan linier,

$$
z_{\mathrm{i}}=c_{1}\left(v_{1}\right)+c_{2}\left(v_{2}\right)+\ldots+c_{\mathrm{n}}\left(v_{\mathrm{n}}\right)
$$

Setelah didapatkan MRP, denoising dilakukan menggunakan MRP pada signal subspace hal ini berlaku pada implementasi yang dilakukan Orchard, namun denoising yang penulis lakukan tetap dilakukan pada full space menggunakan MRP yang didapat.

\section{EKSPERIMEN}

\section{A. Evaluasi Hasil Denoising}

Diperlukan tolak ukur penilian kualitas denoising menggunakan data statistik selain memperhatikan kualitas citra denoise menggunakan pengamatan fisik. Metode pengukuran yang dipergunakan disini menggunakan standar penilaian yang telah umum disepakati: MSE, PSNR, dan SSIM.

Means Squre Error(MSE) merupakan pengukuran selisih rata-rata kuadrat error dua citra. Untuk data 1-d MSE dapat didefinisikan dengan,

$$
M S E=\frac{1}{n} \sum(X i-X j)^{2}
$$

Pendekatan yang sama dilakukan untuk MSE 2-d. Peak Signal To Noise Ratioi(PSNR) merupakan rasio citra sinyal terkorupsi terhadap citra asli. PSNR dapat dihitung menggunakan formula berikut,

$$
P S N R=20 * \log 10\left(\frac{\mathrm{MAXi}}{\sqrt{\mathrm{MSE}}}\right)
$$

PSNR maupun MSE terkadang tidak konsisten dengan persepsi mata manusia[7], oleh sebab itu SSIM dikembangkan mengukur kemiripan antara kedua citra yang diperbandingkan. SSIM metric dihitung dari sejumlah ukuran sub-window yang berbeda antara dua citra. SSIM memiliki nilai $0 \sim 1$. Nilai 1 diberikan untuk dua citra yang identik. Penjelasan lebih lanjut untuk mengetahui formula SSIM dapat dilihat di [7]

\section{B. Hasil Eksperimen dan Analisa}

Eksperimen dilakukan dengan sejumlah skenario pengujian.

\section{Skenario 1}

Skenario pertama dilakukan untuk mengetahui keefektifan NLM dalam denoising white noise dan juga jenis noise lainnya. Untuk percobaan pertama ini, dikonfigurasikan nilai $\sigma=20$. Kemudian parameter denoising menggunakan $k s($ neighborhood window $)=3, \quad s w($ search window $)=2$, $h($ estimasi $\sigma)=20$. Eksperimen denoising untuk citra sinyal terkorupsi noise uniform dapat dilihat pada gambar 6 . 


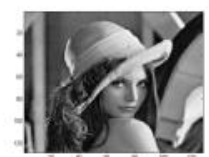

(a) Citra asli

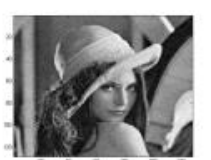

(b) Citra terkorupsi uniform noise, $\sigma=20$

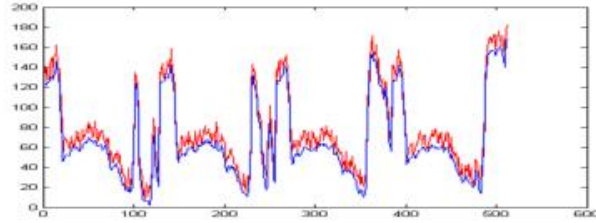

(c)Plot 1-d sampe nilai piksel, mengambill 4 baris pertama nilai piksel dari citra. Garis biru menunjukkan plot citra asli, garis merah menunjukkan plot citra terkorupsi. PSNR $=26.89 \mathrm{db}, \mathrm{SSIM}=0.98$

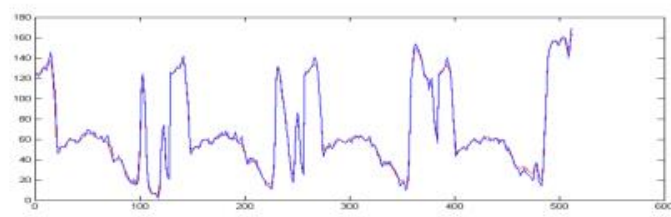

(d) Plot 1-d denoise signal terhadap citra asli. Biru menandakan sinyal asli, merah menandakan sinyal denoise. $\mathrm{PSNR}=31.89 \mathrm{db}, \mathrm{SSIM}=0.92$

\section{Gambar 4. Hasil restorasi citra terkorupsi uniform noise}

Pengamatan secara fisik terhadap citra terestorasi memberikan hasil yang cukup baik kecuali terdapat detail tekstur yang ter-smooth(tekstur topi terutama), dan terdapatnya peningkatan brightness pada sejumlah wilayah(kulit lena). NLM tidak dapat merestorasi citra asli dengan sempurna hal ini terlihat pada gambar 6.d terdapat region dimana terjadi smoothness terutama pada region yang memiliki resonansi tinggi/kaya akan tekstur. Eksperimen berikutnya dilakukan terhadap citra yang terkorupsi white noise dengan nilai $\sigma=10$.

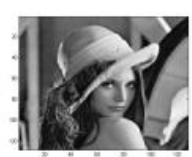

(a) Citra asli

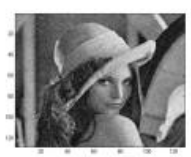

(b) Citra terkorupsi uniform noise, $\sigma=10$

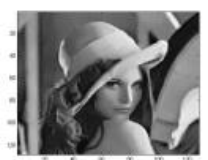

(c) Hasil NLM denoising

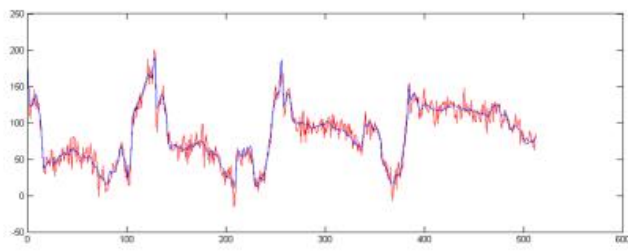

(c) Plot I-d sampe nilai piksel, mengambill 4 baris berurut dari indeks random nilai piksel citra. Garis bir menunjukkan plot citra asti, garis merah menunjukkan plot citra terkorupsi gaussian. PSNR=28.15 db, $\operatorname{SSIM}=0.80$

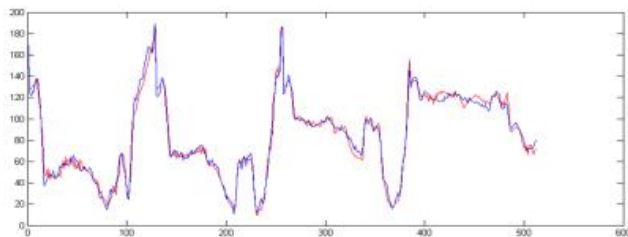

(d) Plot I-d denoise signal terhadap citra asli. Biru menandakan sinyal asli, merah menandakan sinya hasil denoise. PSNR $=31.68 \mathrm{db}, \mathrm{SSIM}=0.93$

\section{Gambar 5. Hasil restorasi citra terkorupsi gaussian noise}

Berdasarkan gambar 7.d, NLM tidak optimal dalam mengestimasi sinyal lena asli dari sinyal yang terkorupsi gaussian noise, hal ini terlihat setidaknya jika diperbandingkan dengan gambar 6.d. dimana deviasi yang terjadi pada sinyal denoise dari sinyal asli cukup bervariatif. Hal ini bisa dimengerti sebab karakteristik dari gaussian noise yang turut memperhitungkan nilai negatif dalam menghasilkan sinyal noise sehingga estimasi sinyal asli lebih sulit untuk dilakukan. Yang menarik informasi SSIM terhadap sinyal terestorasi menunjukkan kualitas yang lebih baik dari sinyal terestorasi dari uniform noise(0.93 vs 0.92), hal ini sejalan dengan pengamatan fisik dimana masih terdapat tekstur yang masih terjaga setelah dilakukan denoising.

Eksperimen berikutnya dilakukan terhadap noise salt \& pepper(SP), dimana setiap piksel memiliki kemungkinan tertentu untuk berubah nilainya menjadi 0 atau 255. Efek dari noise ini pada citra adalah munculnya bintik hitam dan putih pada citra terkorupsi. NLM melakukan denoising terhadap seluruh piksel, karena SP merubah nilai piksel pada indeks tertentu saja, NLM perlu dimodifikasi terlebih dahulu agar hanya mengolah piksel yang terkena salt \& pepper. 


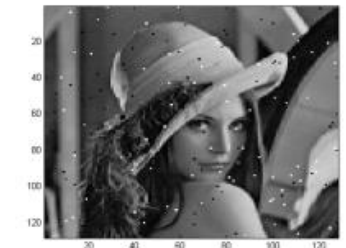

(a) Citra terkorupsi noise salt \& pepper probabilitas terkena $\mathrm{SP}$ adalah $0.01(1 \%)$

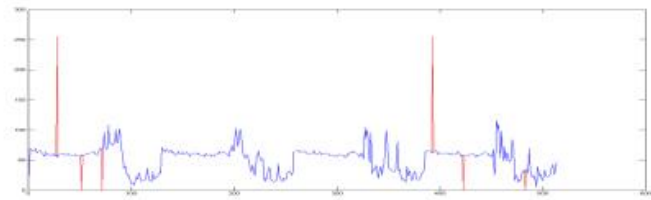

(c)Plot 1-d sampe nilai piksel, mengambill 4 baris berurut dari indeks random nilai piksel citra. Garis biru menunjukkan plot citra asli, garis merah menunjukkan plot citra terkorupsi salt \& pepper. PSNR $=25.5 \mathrm{db}$ $\operatorname{SSIM}=0.86$

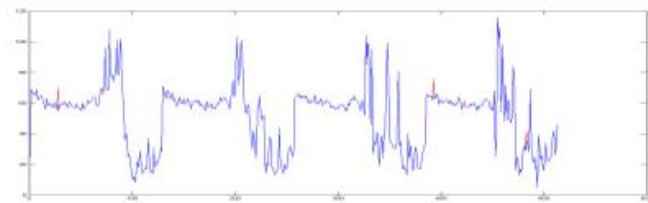

(c) Plot 1-d denoise signal terhadap citra asli. Biru menandakan sinyal asli, merah menandakan sinyal hasil denoise. PSNR=42. SSIM $=0.9942$

\section{Gambar 6. Hasil restorasi citra terkorupsi salt \& pepper}

Selektif NLM mampu merestorasi citra yang mendekati asli. Namun hasil ini didapat dengan sejumlah catatan: Parameter search window atau neighborhood window sangat tidak berpengaruh terhadap hasil denoising, bahkan mengatur full search window hampir tidak berpengaruh. Parameter $h$ (decay parameter) memiliki efek yang signifikan terhadap hasil denoising, ketika nilai $h>40$ atau $h<40$ kualitas citra terestorasi sedikit menurun. Sedikitnya pengaruh search window atau neighborhood window disebabkan karena kebanyakan piksel tetangga akan tidak relevan dengan POI sehingga dialokasikan weight yang sangat kecil, dalam hal ini POI merupakan outlier terhadap piksel tetangga.

\section{Skenario 2}

Tujuan dari eksperimen kedua adalah untuk membuktikan NLM MRP mampu memberikan hasil denoising yang lebih baik dari NLM standar. Metode NLM MRP menggunakan implementasi Orchard, hal ini disebabkan denoising menggunakan MRP pada signal subspace lebih masuk akal, dan pendekatan inilah yang dipergunakan juga pada [6].

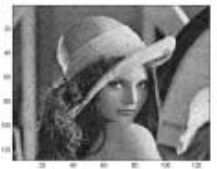

(a) Citra terkorupsi gaussian noise. $\sigma=10$

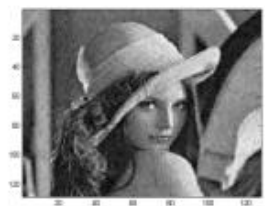

(d) Denoising NLM MRP dengan $h=20$

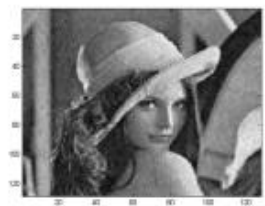

(f) Denoising NLM MRP dengan $h=20$ (b) Denoising NLM MRP

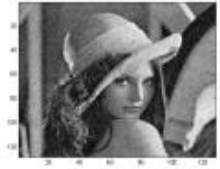

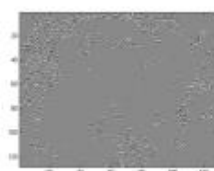

(c) Bintik putih menunjukkan noise yang terestorasi

$$
\text { dengan } h=10
$$

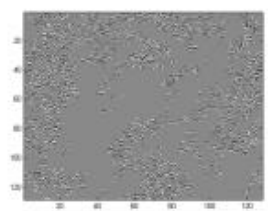

(e) Semakin banyak piksel yang terestoras

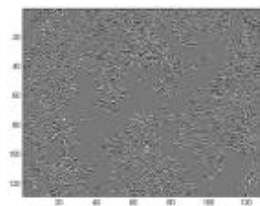

(g) Semakin banyak piksel yang terestorasi kecuali tekstur topi dan rambut.

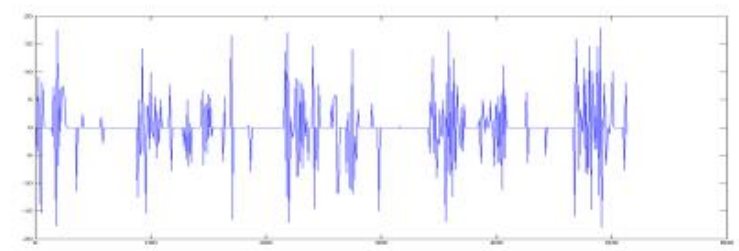

(h) Plot sinyal noise yang terestorasi, daerah flat menunjukkan lokai noise yang tidak disentuh.

\section{Gambar 7. Hasil denoising menggunakan NLM MRP}

Percobaan denoising menggunakan NLM MRP menunjukkan, NLM MRP tidak merestorasi seluruh piksl yang terkena noise. Dari informasi yang disajikan pada gambar 9, mayoritas hanya tekstur smooth yang dihilangkan noise-nya. Melihat data ini, NLM masih memiliki kinerja yang lebih baik namun sifat dari NLM MRP yang melakukan denoising daerah tertentu saja merupakan sebuah fakta yang menarik, sangat mungkin noise yang terestorasi merupakan estimasi noise yang sangat baik pada daerah yang terestorasi. Berdasarkan karakteristik ini NLM MRP dapat dijadikan sebagai preprocessing dalam tahap denoising menggunakan NLM.

\section{Skenario 3}

Eksperimen ketiga bertujuan untuk mencari parameter optimal NLM untuk denoising white noise Benchmark dilakukan menggunakan test script Matlab yang dirancang untuk memaksimalkan nilai SSIM dengan mencoba semua kemungkinan search window, neighborhood window, dan $h$ dengan interval tertentu. Karena benchmark terhadap ketiga ketiga tersebut memakan waktu yang lama, benchmark disederhanakan menggunakan dua fase: fase pertama bertujuan untuk mengoptimasi parameter search window dan neighborhood window(2-D), dan fase kedua bertujuan untuk 
mengoptimasi parameter $h$. Pada eksperimen ini citra terkorupsi gaussian noise dengan $\sigma=15$.

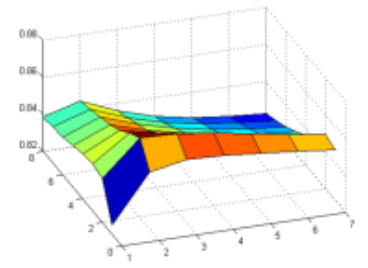

(a) Parameter optimal search window, dan search window didapatkan ketika keduanya masih bernilai kecil.

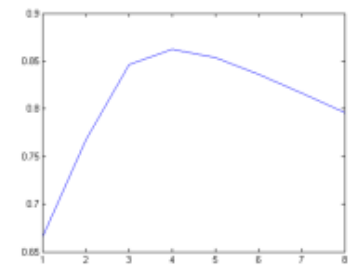

(c) Parameter optimal $h$ didapatkan ketika $h$ memiliki nilai yang sangat mendekati $\sigma$

\section{Gambar 8. Benchmark Parameter NLM untuk mencapai SSIM terbaik.}

Parameter $h$ (decay parameter) merupakan estimasi dari $\sigma$, sehingga wajar jika SSIM bernilai optimal saat $h=\sigma$. Analisa lebih lanjut diperlukan untuk mengetahui kenapa search window dan neighborhood window bernilai optimal ketika keduanya bernilai kecil. Hal ini kontradiktif dengan yang karakteristik NLM yang seharusnya bernilai optimal ketika menjalankan full search space. Setidaknya terdapat dua hal yang menyebabkan hal ini terjadi: Konfigurasi pembentukan gaussian kernel untuk menghitung L2 norm dari dua neighborhood window, pembentukan gaussian kernel pada implementasi mempergunakan rumus (p3) dimana setiap indeks pada gaussian kernel dihitung dengan $\frac{1}{2 f+1}$. Kedua, nilai similaritas dua neighborhood window sangat ditentukan oleh weight yang dihitung menggunakan $(p 2)$.

Weight merupakan distribusi eksponsensial: $w=e^{\frac{-d}{h}}$, perhatikan $d$ pasti bernilai positif karena merupakan bentuk kuadrat(euclidean distance antara dua patch), sehingga nilai -d bernilai negatif. Untuk patch/neighborhood window yang tidak similar, nilai $d$ akan sangat besar, sehingga ketika dinegatifkan melalui $e$ akan bernilai mendekati 0. Permasalahannya melalui konfigurasi gaussian kernel yang memiliki elevasi tidak terlalu curam(gambar 2), weighted similarities antara dua patches ketika memiliki gaussian kernel yang relatif besar akan memberikan hasil yang buruk sebab informasi yang relevan sangat mungkin ditemukan pada tetangga piksel neighborhood window yang diperbandingkan. Atas dasar ini patch sebaiknya diatur kecil, kecuali formula pembentukan gaussian kernel dimodifikasi.

Averaging dilakukan terhadap penjumlahan dari weighted similarities untuk POI, over estimasi akan dihasilkan ketika jumlah piksel yang di-averaging melebihi rasio yang dibutuhkan. Atas dasar ini, search window sebaiknya diset tidak terlalu besar, 7 piksel sekitar POI merupakan nilai yang ideal.

\section{PENUTUP}

Re-eksperimentasi ini merupakan upaya untuk mengimprovisai algoritma NLM. Improvisasi tidak mungkin dilakukan tanpa pemahaman yang kokoh terhadap NLM, untuk itulah dilakukan analisa yang laporannya dijabarkan pada tulisan ini. Upaya mengimprovisasi NLM sudah dilakukan menggunakan NLM MRP, implementasi yang penulis lakukan menggunakan persepsi yang dijelaskan pada bagian IV tidak memberikan hasil yang lebih baik dari NLM original, untuk itulah fokus analisa dilakukan menggunakan NLM MRP yang diperkenalkan Orchard.

\section{REFERENSI}

[1] Antoni Buades, Bartomeu Coll, Jean-Michel Morel. A nonlocal algorithm for image denoising. Tracked on CiteSeerX with total 60 citations. 2005.

[2] Antoni Buades, Bartomeu Coll, Jean-Michel Morel. A Review Of Image Denoising Algorithms With a New One. Society for Industrial and Applied Mathematics Journal vol 4, no 2, pp 490-530. 2005.

[3] Jeff Orchard, Mehran Ebrahimi, Alexander Wong. Efficient Nonlocal-Means Using The SVD. 15th IEEE International Conference on Image Processing, 2008. ICIP 2008.

[4] Antoni Buades, Bartomeu Coll, Jean-Michel Morel. Image and Movie Denoising by Non Local Means. International Journal of Computer Vision vol 76, Issue 2. 2008.

[5] Thanaphol Thaipanich, et al. Improved Image Denoising with Adaptive Nonlocal Means Algorithm. International Conference on Consumer Electronics(ICCE), Las Vegas, 2010.

[6] Yanmin He et al. Adaptive Denoising by Singular Value Decomposition. IEEE Signal Processing Letter vol 18, no 4, April 2010.

[7] http://en.wikipedia.org/wiki/Structural_similarity, Structural Similarity, diakses pada Juni 2011. 